Chirurgia (2019) 114: 622-629

No. 5, September - October

Copyright $@$ Celsius

http://dx.doi.org/10.21614/chirurgia.114.5.622

\title{
Risk Assessment and Learning Curve in Laparoscopic Transperitoneal Adrenalectomy - Early and Late Experience of a Single Team
}

\author{
Adrian Miron, Octavian Enciu, Elena Adelina Toma, Valentin Calu
}

Department of Surgery, Elias University Emergency Hospital, Bucharest, Romania

Corresponding author:

Octavian Enciu, MD

Elias University Emergency Hospital

Blvd. Mărăsti nr. 17 Sector 1

Bucharest, Romania

E-mail: esoctavian@gmail.com

\section{Rezumat \\ Riscul chirurgical și curba de învătare în suprarenalectomia laparoscopică transperitoneală: experienta unei singure echipe}

De la prima sa descriere în 1992, suprarenalectomia laparoscopică a devenit standardul de tratament pentru majoritatrea tumorilor suprarenaliene benigne, însă din cauza incidenței scăzute a acestora, rămâne o intervenție rar efectuată în afara centrelor de excelență. Deşi chirurgia laparoscopică a avut un impact pozitiv asupra complicațiilor suprarenalectomiei, abordul chirurgical trebuie evaluat cu atenție în cazurile tumorilor secretante sau de mari dimensiuni. Prezentăm o analiză retrospectivă a suprarenalectomiilor laparoscopice efectuate în primii cinci ani de practică - 2007-2010, experiență timpurie ce include şi curba de învățare a chirurgului principal şi experiența recentă 2016-2019. Toate intervențiile au fost efectuate de o singură echipă chirurgicală condusă de un chirurg cu experiență semnificativă în chirurgie laparoscopică avansată, folosind abordul lateral transperitoneal. În total au fost incluse 82 cazuri din cele 153 identificate între 20072019. A fost notat un singur caz de conversie la chirurgie deschisă în prima parte a curbei de învățare şi două reintervenții laparoscopice necesare pentru hemostază şi drenaj. Adenoamele nesecretante au reprezentat cea mai frecventă indicație chirurgicală (26 cazuri), urmate de sindromul Cushing (22 cazuri) în timp ce carcinomul adrenocortical a fost diagnosticat în 3 cazuri. Diferente semnificative au fost observate între cele două grupuri studiate în ceea ce priveşte timpul operator (116.35 minute vs. 89.35 minute) şi durata medie spitalizării postoperatorii (5.83 zile vs. 3.7 zile) $(p<0.001)$. Odată cu creşterea experienței în efectuarea 
suprarenalectomiei transperitoneale laparoscopice, scăderea incidenței complicațiilor, a timpului operator şi a duratei de spitalizare sunt de aşteptat.

Cuvinte cheie: suprarenalectomie laparoscopică transperitoneală, risc chirurgical, curbă de învățare

\begin{abstract}
Since its first description in 1992, laparoscopic adrenalectomy has become the standard of treatment for most benign and low grade small adrenal tumors but due to the low incidence of adrenal disease, it remains a rarely performed intervention outside referral or excellence centers. Although laparoscopic surgery had a positive impact on complications of adrenalectomy, surgical risk should be thoroughly assessed when it comes to secreting or large tumors. This is a retrospective analysis of laparoscopic adrenalectomies performed in the first 4 years of practice 2007-2010 - the early experience including the learning curve of the senior surgeon, and our late experience from 2016 to 2019. All interventions were performed by a single team led by a senior surgeon with extensive experience in advanced laparoscopic surgery, using the lateral transperitoneal approach. In total, 82 cases were included, out of 153 laparoscopic adrenalectomies performed between 2007 and 2019. Only one conversion was recorded during the early experience and two laparoscopic reinterventions were needed for hemostasis and drainage. Non-secreting adenoma was the most frequent indication for surgery (26 cases) followed by Cushing's Syndrome (22 cases) while adrenocortical carcinoma was diagnosed in 3 cases. Significant differences were found between the two periods regarding operative time and length of postoperative hospital stay $(\mathrm{p}<0.001)$. With growing experience in laparoscopic transperitoneal adrenalectomy, less complications and shorter operative time and postoperative hospital stay are to be expected.
\end{abstract}

Key words: laparoscopic transperitoneal adrenalectomy, surgical risk, learning curve

\section{Introduction}

Adrenal surgery entered the age of laparoscopy in 1992 and became the "standard of treatment" for both secreting and non-secreting tumors a decade later $(1,2)$. To the present day, the role of laparoscopic surgery for malignant tumors is under scrutiny. Apart from clinically evident and documented endocrine diseases and metastatic disease, the incidence of adrenal tumors rose with increased use of imaging studies such as CT and MRI scans (3,4). In a parallel fashion, with the advent of laparoscopy, it is feasible to imagine that the number of laparoscopic adrenalectomies performed rose for tumors that otherwise wouldn't have been diagnosed or would have been below the indication threshold for open adrenalectomy (5-7). Fewer complications after laparoscopic than after open adrenalectomy enthusiastically increased the number of interventions (8). Thusly, accurate diagnosis by imaging studies would provide unambiguous surgical indication. Most units form multidisciplinary boards for adrenal tumors.

Regarding surgery, risk assessment has the objective to reduce morbidity and mortality. To further lower the risk, timing of surgery and optimal surgical approach are important - the retroperitoneoscopic approach might lower the surgical risk for obese patients with smaller tumors and for patients with previous abdominal operations while the transperitoneal approach would favor larger tumors. As for any type of surgery, surgical technique is paramount and the learning curve for less frequent interventions such as laparoscopic adrenalectomy is difficult to overcome in non- 
referral centers. Intraoperative incidents and evidence of malignancy may require conversion, although with growing experience the rate of conversion for bleeding incidents should be expected to decrease. It is not difficult to understand why mentorship and/or proctorship is needed during the learning curve and after its completion. Even if the preoperative and intraoperative risk assessment was optimal, the postoperative risk assessment for secreting tumors begins intraoperatively. Postoperative vigilant follow-up should be carried out in a multidisciplinary fashion.

The quality of preoperative risk assessment equals the quality of available information therefore preoperative workup should be as accurate as possible (9).

Most adrenal tumors will undergo laparoscopic resection, with minimal morbidity and close to nil mortality. But this approach is not exclusive, large tumors (more than $6 \mathrm{~cm}$ in diameter), evidence of local invasion and suspected metastatic lymph nodes should prompt for open surgery.

\section{Material and Method}

The surgical data base of patients that underwent laparoscopic adrenalectomy at Elias University Emergency Hospital was analyzed. Out of 153 laparoscopic adrenalectomies performed during 2007 and 2019, 82 cases were included in the study: 37 cases performed between 2007 when the procedure was introduced and 2010 and 45 cases performed during the last 4 years, 2016-2019 (September). Comparisons were made between the two groups in terms of age at diagnosis, sex, type of disease and indication for surgery, adrenal tumor size, operative time and postoperative hospital stay. All interventions were made by a single team led by a senior surgeon with extensive experience in advanced laparoscopic surgery using the lateral transperitoneal approach.

For statistical analysis (two-tailed t-test, Fisher's exact test and Chi-square where appropriate) the SPSS version 20.0 (SPSS Inc., Chicago, IL, USA) was used and p-values lower than 0.05 were considered to be significant. The study was approved by our institutional ethics committee.

The indications for laparoscopic adrenalectomy during the two groups 2007-2010 and 2016-2019 are listed in Fig. 1. Right and left sided laparoscopic adrenalectomies were compared between the two groups.
Figure 1. Indications for Laparoscopic Adrenalectomy

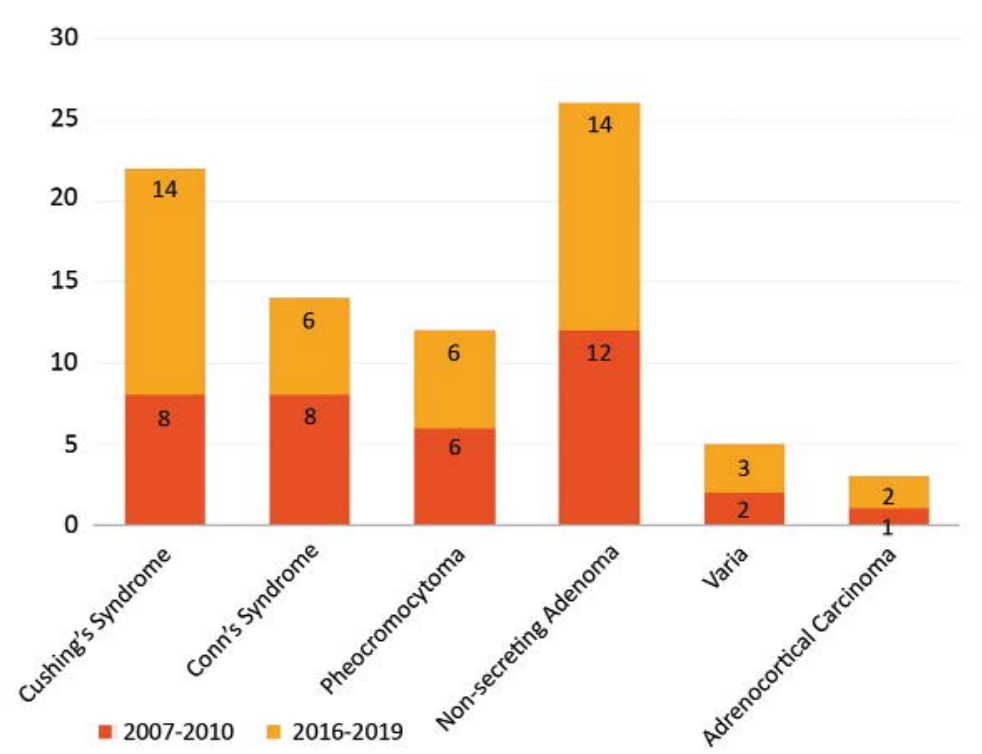

| 2007-2010 || 2016-2019 


\section{Results}

During the first four years since laparoscopic adrenalectomy was introduced in our department, 37 interventions were performed, 16 right and 21 left laparoscopic adrenalectomies. In this first group, there were 14 men and 23 women with a mean age of 50.4 years (26-73 years). The most frequent indication for surgery as revealed by the pathology reports was non-secreting adenoma (12 cases) followed by Cushing's syndrome (8 cases) and Conn's syndrome (8 cases). Six patients diagnosed with pheochromocytoma were operated during the early experience while adrenocortical cancer was diagnosed inadvertently at final pathology. The mean operative time was $116.35 \mathrm{~min}$ (80-145 $\mathrm{min}$ ) and mean postoperative stay was 5.83 days (4-8 days).

Most adrenal tumors had between 4 and 6 $\mathrm{cm}$ in size (17 cases), we found 12 tumors smaller than $4 \mathrm{~cm}$ and 8 tumors were larger than $6 \mathrm{~cm}$.

During the early experience, one conversion and one laparoscopic reintervention were required for bleeding control.

From 2016 to 2019, 45 laparoscopic adrenalectomies were performed. As shown by the listing in Fig. 1, more patients diagnosed with Cushing's Syndrome were operated on during this period. The mean operative time decreased to 89.35 minutes (55-125 minutes) and the mean postoperative hospital stay to 3.7 days (2-7 days). Most adrenal tumors had between 4 and $6 \mathrm{~cm}$ in size (19 cases) $11 \mathrm{had}$ less than $4 \mathrm{~cm}$ and 15 tumors were larger than $6 \mathrm{~cm}$.

No conversions were recorded between 2016-2019. One laparoscopic reintervention was needed for postoperative pancreatic fistula and left subphrenic abscess.

Table 1 summarizes the differences between the two groups regarding right laparoscopic adrenalectomy.

In terms of operative time and length of postoperative hospital stay, notable differences were found. Operative time decreased remarkably (112.5 minutes vs 78.43 minutes, $\mathrm{p}<0.001$ ) as well as the length of postoperative hospital stay (5.81 days vs 3.43 days, $\mathrm{p}<0.001$ ).

Table 2 summarizes the differences between the two groups regarding left laparoscopic adrenalectomy.

For left laparoscopic adrenalectomy operative time decreased from 119.2 minutes to 95.17 minutes $(\mathrm{p}<0.001)$ while the postoperative hospital stay decreased from 5.85 days (4-8 days) to 3.72 days ( $2-7$ days $)(p<0.001)$.

\section{Discussion}

Adrenal surgery is needed for secreting

Table 1. Right Laparoscopic Adrenalectomy

\begin{tabular}{|c|c|c|c|c|}
\hline \multicolumn{2}{|c|}{ Right Laparoscopic Adrenalectomy } & \multirow{2}{*}{$\begin{array}{c}2007-2010 \\
(n=16)\end{array}$} & \multirow{2}{*}{$\begin{array}{c}\begin{array}{c}2016-2019 \\
(n=16)\end{array} \\
2\end{array}$} & \multirow{2}{*}{\begin{tabular}{|c|} 
P value \\
0.220
\end{tabular}} \\
\hline Sex & $M$ & & & \\
\hline & $\mathrm{F}$ & 10 & 14 & \\
\hline Age (mean, years) & & $53(26-73)$ & $47.88(23-72)$ & 0.312 \\
\hline \multirow[t]{6}{*}{ Disease } & Cushing's & 4 & 4 & 0.747 \\
\hline & Conn's & 3 & 3 & \\
\hline & Pheochromocytoma. & 4 & 2 & \\
\hline & Non-secreting Adenoma & 3 & 6 & \\
\hline & Cancer & 1 & 0 & \\
\hline & Other & 1 & 1 & \\
\hline \multirow[t]{3}{*}{ Tumor size $(\mathrm{cm})$} & $<4$ & 7 & 2 & 1.000 \\
\hline & $4-6$ & 8 & 10 & \\
\hline & $>6$ & 1 & 4 & \\
\hline \multicolumn{2}{|c|}{ Operating time (mean,min) } & $112.5(80-145)$ & $78.43(55-110)$ & $<0.001$ \\
\hline \multicolumn{2}{|c|}{ Length of Postop Hospital Stay (days) } & $5.81(3-8)$ & $3.43(2-6)$ & $<0.001$ \\
\hline
\end{tabular}


Table 2. Left Laparoscopic Adrenalectomy

\begin{tabular}{|c|c|c|c|c|}
\hline \multicolumn{2}{|c|}{ Left Laparoscopic Adrenalectomy } & \multirow{2}{*}{$\begin{array}{c}\begin{array}{c}2007-2010 \\
(n=29)\end{array} \\
8 \\
13\end{array}$} & \multirow{2}{*}{$\begin{array}{c}\begin{array}{c}\mathbf{2 0 1 6} \\
(\mathbf{n}=\mathbf{2 1})\end{array} \\
7 \\
22\end{array}$} & \multirow{2}{*}{$\begin{array}{c}\text { P value } \\
0.355\end{array}$} \\
\hline Sex & $\begin{array}{l}M \\
F\end{array}$ & & & \\
\hline Age (mean, years) & & $48.42(28-72)$ & $52.68(17-77)$ & 0.298 \\
\hline Disease & $\begin{array}{l}\text { Cushing's } \\
\text { Conn's } \\
\text { Pheochromocytoma. } \\
\text { Non-secreting Adenoma } \\
\text { Cancer } \\
\text { Other }\end{array}$ & $\begin{array}{l}4 \\
5 \\
2 \\
9 \\
0 \\
1\end{array}$ & $\begin{array}{c}10 \\
3 \\
4 \\
8 \\
2 \\
1\end{array}$ & 0.567 \\
\hline Tumor size $(\mathrm{cm})$ & $\begin{array}{l}<4 \\
4-6 \\
>6\end{array}$ & $\begin{array}{l}5 \\
9 \\
7\end{array}$ & $\begin{array}{c}9 \\
9 \\
11\end{array}$ & 0.116 \\
\hline Operating time (me & & $119.2(95-140)$ & $95.17(75-145)$ & $<0.001$ \\
\hline Length of Postop H & ays) & $5.85(4-8)$ & $3.72(2-7)$ & $<0.001$ \\
\hline
\end{tabular}

tumors that arise from the adrenal cortex or medulla, primary and secondary malignancies of the adrenal gland, unsuccessful pituitary surgery and adrenal incidentaloma.

Pheochromocytoma, a rare neuroendocrine tumor arising from the adrenal medulla, mostly benign but not exclusively, has a firm surgical indication but demands thorough preoperative and postoperative management, firstly to avoid catecholamine storm during surgery but also to prevent hemodynamic instability after surgery $(10,11)$. Before this need was acknowledged, the reported operative mortality ranged was $30-45 \%$, but present surgical advances, imaging techniques and anesthetic management led to less than 3\% per-operative mortality $(12,13)$. In our series, the postoperative hospital stay decreased significantly due to better cardiovascular management, while all tumors in both groups were at least $4 \mathrm{~cm}$ in size (Fig. 2).

Diagnosed incidentalomas over $4 \mathrm{~cm}$ in size, or with at least $20 \% / 5 \mathrm{~mm}$ increase in size over 12 months of follow-up, secreting incidentalomas and atypical lesions with intratumoral radiological signs of malignancy, regardless of size should undergo surgery (14). Nevertheless, biochemical profiling and hormonal testing is needed for excluding subclinical conditions. With a prevalence of $2 \%$ in autopsy studies, and a slightly higher prevalence in radiological studies, the vast majority of incidentalomas are benign $(4,15)$. The size of the incidentally found adrenal mass is very important because $6 \%$ of incidentalomas with diameter between 4 and $6 \mathrm{~cm}$ and $25 \%$ to $28 \%$ of incidentalomas larger than $6 \mathrm{~cm}$ are reported to be malignant $(2,16,17)$. Regarding size at diagnosis and follow-up, one should be aware of the differences in size found during CT scan and the final resection specimen. Several studies have found that computed tomography underestimates by approximately

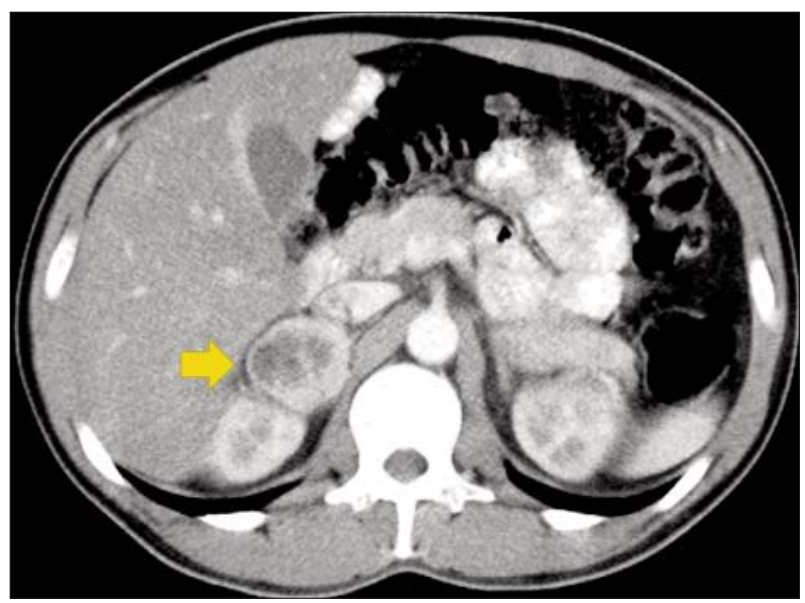

Figure 2. Right $5 / 5 \mathrm{~cm}$ Pheochromocytoma in a 47 -year-old man 
$20 \%$ the size of adrenal tumors and a mathematical correction has been proposed $(18,19)$. Current published data advise against adrenal fine needle biopsy for adrenal incidentalomas (15). Overall, in both studied groups, incidentalomas represented the most frequent indication for surgery. After final pathology, 1 incidentaloma in each group turned out to be adrenocortical carcinoma, both being incidentally diagnosed as non-secreting adrenal tumors smaller than $4 \mathrm{~cm}$.

The lateral transperitoneal approach is the most practiced approach and given the wider working space is suitable for larger tumors. Other intra-abdominal conditions may be resolved during the intervention, but postoperative adhesions can lengthen the procedure. If bilateral adrenal resection is planned, change of position is needed. The lateral decubitus position required for lateral transperitoneal adrenalectomy exposes the patient to several risks: sacral and brachial plexus nerve and compression lesions, and all need to be addressed. The risk for deep vein thrombosis is elevated in Cushing's Syndrome, and these patients might need additional prophylaxis on discharge (20).

Successful laparoscopic resections for large adrenal tumors have been reported in referral centers but this approach should be carefully planned by experts and under recent guidelines should not be encouraged $(21,22)$. Large tumors have larger surface are and will take longer time for dissection and are more likely to convert (23). In a linear fashion, dissection time increases by 10 minutes for every centimeter of tumor diameter and tumors with diameter larger than 6 centimeters have a $12.5 \%$ conversion rate, mostly because of technical problems $(23,24)$. During initial laparoscopy, if evidence of malignant disease or local invasion is present, conversion is advised for oncological reasons in order to obtain a R0 resection. Overall, 23 adrenal tumors over $6 \mathrm{~cm}$ in size were resected between 2007 and 2019 without incidents. During the late experience, laparoscopic adrenalectomy was performed in one case for suspected adrenocortical carcinoma measuring
$6.5 \mathrm{~cm}$ but without lymph node metastases and signs of local invasion. Final pathology report confirmed complete resection and the patient had an uneventful postoperative course and is free from disease two years after surgery.

The most common cause of conversion in laparoscopic adrenalectomy is bleeding, although it is seldom life threatening or as a result of major vascular injury (25). With increased experience the need to convert may minimize and even complex lesions such as adrenal vein avulsion or inferior vena cava tear can be managed laparoscopically. In our series, one conversion was necessary during the initial experience, for bleeding without a large visible vessel. Reintervention was necessary in two cases and both were accomplished by laparoscopic surgery. In one case bleeding control was necessary but no large vessel injury was identified and one case needed reoperation for left subphrenic abscess due to pancreatic fistula.

Extracapsular dissection with preservation of the capsule of the adrenal is recommended, but partial adrenalectomy has been reported with very good results for a variety of benign conditions, especially for bilateral adrenal masses, and avoids medical adrenal replacement $(26,27)$. The amount of cortical tissue needed for normal function is $1 / 3$ of one gland and blood supply needs to preserved without mobilization out of the retroperitoneum (28). Between 2016 and 2019, 4 partial laparoscopic adrenalectomies were performed for Cushing's Syndrome. Two young female patients received sequential bilateral partial laparoscopic adrenalectomies for Cushing's Syndromes with bilateral secreting adenomas, both of them being asymptomatic at present and not needing substitution treatment (27).

Laparoscopic adrenalectomy is an ablative procedure that carries an important hemorrhagic risk (29). It should not be approached at the beginning of laparoscopic experience because the surgeon must already have the necessary skills acquired in the previous lower level of difficulty operations, besides a proper technical endowment.

Courses, training and individual study 
should provide basic and solid notions of anatomy of the area and operating steps (30). But the complexity of the anatomy, differences on the right and the left side, patient's status and obesity can pose serious challenges with potentially catastrophic outcomes for an inexperienced surgeon (25). One can discover from the start that even the placement of trocars should be adapted and textbook recommendations do not work every time. It's at that time when a deep knowledge of anatomy and surgical technique doubled by spatial orientation proves to be beneficial. Another issue is that the adrenal gland is brittle and bleeds easily; a small amount of blood can be very upsetting when operating in such a narrow space therefore the manipulation of the gland should be minimal, especially in pheochromocytoma $(31,32)$.

When approaching a new technique there are several quantifiable factors to be taken into consideration, as the duration of surgery, blood loss, morbidity, conversions, patient's outcome. All summed up to reflect the surgeons' performance while ascending the learning curve, which is usually longer for difficult operations, such as laparoscopic adrenalectomy. Various authors consider a number between 20 to 40 cases as required for a surgeon to master this technique but this can be influenced by other factors such as the surgeon's previous experience and pre-implementation training $(33,34)$. The intervention was introduced at Elias University Emergency Hospital by a senior surgeon with extensive previous experience in laparoscopic surgery after having observed the intervention and trained during two fellowships.

At the beginning of the experience difficult cases, such as tumors larger than $3-4 \mathrm{~cm}$, obese patients or pheochromocytomas should be avoided (35). A good selection of easier cases will allow the surgeon to surpass the challenges of the first operation and learn or rediscover the tips and tricks of this procedure, with a greater benefit for those with previously acquired knowledge during training
(36). A very short middle adrenal vein on the right side or problems locating the adrenal gland on the left side can be tough experiences. In our series, growing experience has shown to lower the operative time and remarkably more for left sided than for right sided adrenalectomies. Operative time was lower than reported by other authors presumably due to previous experience in laparoscopic surgery.

Even when the learning curve has been surpassed and the surgeon is considered experienced, he or she should expect the unexpected, since the experience is indicated by the capacity to adapt to unforeseen situations. Mentorship has been proved to further improve performance in regard to operative time and hospital stay for retroperitoneoscopic adrenalectomy (37).

Although most case series studies report very low morbidity and close to zero mortality, Tessier end al. published a series of high-grade complications that occurred outside referral hospitals (25). All these major complications, like complete transections of porta hepatis, hepatic artery ligation or ureteral ligation during left adrenalectomy were regarded as a consequence of inexperience but may be attributed to misperception - human error not related to skill or knowledge. Heuristics as problem-solving unconscious processes that function rapidly, do not always provide correct solutions. Visual perception is one such example and laparoscopic adrenalectomy as the more intensely studied laparoscopic cholecystectomy, is mostly based on visual information (38).

\section{Conclusion}

Implementation in practice of lateral transperitoneal laparoscopic adrenalectomy is feasible and safe with prior experience in advanced laparoscopic surgery that sweepingly shortens the learning curve. With growing experience, complication and conversion rates as well as operative time and postoperative hospital stay should be expected to decrease. 


\section{Conflict of Interest}

The authors declare no conflicts of interests.

\section{References}

1. Gagner M, Lacroix A, Bolte E. Laparoscopic adrenalectomy in Cushing's syndrome and pheochromocytoma. The New England journal of medicine. 1992;327(14).

2. Nih C. state-of-the-science statement on management of the clinically inapparent adrenal mass ("incidentaloma"). NIH Consens State Sci Statements. 2002;19:1-25.

3. Bovio S, Cataldi A, Reimondo G, Sperone P, Novello S, Berruti A, et al. Prevalence of adrenal incidentaloma in a contemporary computerized tomography series. Journal of endocrinological investigation. 2006;29(4):298-302.

4. Grumbach MM, Biller BM, Braunstein GD, Campbell KK, Carney JA, Godley PA, et al. Management of the clinically inapparent adrenal mass (incidentaloma). Annals of internal medicine. 2003; 138(5):424-9.

5. Saunders BD, Wainess RM, Dimick JB, Upchurch GR, Doherty GM, Gauger PG. Trends in utilization of adrenalectomy in the United States: have indications changed? World journal of surgery. 2004;28(11):1169-75.

6. Henneman D, Chang Y, Hodin RA, Berger DL. Effect of laparoscopy on the indications for adrenalectomy. Archives of Surgery. 2009;144(3):255-9.

7. Gallagher SF, Wahi M, Haines KL, Baksh K, Enriquez J, Lee T-M, et al. Trends in adrenalectomy rates, indications, and physician volume: a statewide analysis of 1816 adrenalectomies. Surgery. 2007;142(6):1011-21.

8. Brunt L. The positive impact of laparoscopic adrenalectomy on complications of adrenal surgery. Surgical Endoscopy And Other Interventional Techniques. 2002;16(2):252-7.

9. Tate L, Feeney A. The principles of risk assessment. Medicine. 2012;40(11):574-6.

10. Pacak K. Preoperative management of the pheochromocytoma patient. The Journal of Clinical Endocrinology \& Metabolism. 2007;92(11):4069-79.

11. Bruynzeel H, Feelders R, Groenland T, Van Den Meiracker A, Van Eijck C, Lange J, et al. Risk factors for hemodynamic instability during surgery for pheochromocytoma. The Journal of Clinical Endocrinology \& Metabolism. 2010;95(2):678-85.

12. Hull C. Phaeochromocytoma: diagnosis, preoperative preparation and anaesthetic management. British Journal of Anaesthesia. 1986;58(12):1453-68.

13. Lenders JW, Eisenhofer G, Mannelli M, Pacak K. Phaeochromocytoma. The Lancet. 2005;366(9486):665-75.

14. Gaujoux S, Mihai R, ESES JWGo, ENSAT, Carnaille B, Dousset B, et al. European Society of Endocrine Surgeons (ESES) and European Network for the Study of Adrenal Tumours (ENSAT) recommendations for the surgical management of adrenocortical carcinoma. British Journal of Surgery. 2017;104(4):358-76.

15. Fassnacht M, Arlt W, Bancos I, Dralle H, Newell-Price J, Sahdev A, et al. Management of adrenal incidentalomas: European society of endocrinology clinical practice guideline in collaboration with the European network for the study of adrenal tumors. European Journal of Endocrinology. 2016;175(2):G1-G34.

16. Grogan RH, Mitmaker E, Vriens MR, Harari A, Gosnell JE, Shen WT, et al. Adrenal incidentaloma: does an adequate workup rule out surprises? Surgery. 2010;148(2):392-7.

17. Bertherat J, Mosnier-Pudar H, Bertagna X. Adrenal incidentalomas. Current opinion in oncology. 2002;14(1):58-63.

18. Linos DA, Stylopoulos N. How Accurate Is Computed Tomography in Predicting the Real Size of Adrenal Tumors?: A Retrospective Study. Archives of Surgery. 1997;132(7):740-3.

19. Fajardo R, Montalvo J, Velázquez D, Arch J, Bezaury P, Gamino $R$, et al. Correlation between radiologic and pathologic dimensions of adrenal masses. World journal of surgery. 2004;28(5):494-7.

20. Babic B, De Roulet A, Volpe A, Nilubol N. Is VTE Prophylaxis Necessary on Discharge for Patients Undergoing Adrenalectomy for Cushing Syndrome? Journal of the Endocrine Society. 2018;3(2):304-13.

21. Bhat HS, Nair TB, Sukumar S, Saheed CM, Mathew G, Kumar PG. Laparoscopic adrenalectomy is feasible for large adrenal masses> $6 \mathrm{~cm}$. Asian Journal of surgery. 2007;30(1):52-6.

22. HOBART MG, GILL IS, SCHWELZER D, SUNG GT, BRAVO EL. Laparoscopic adrenalectomy for large-volume $(\geq 5 \mathrm{~cm})$ adrenal masses. Journal of endourology. 2000;14(2):149-54.

23. Berber $\mathrm{E}$, Duh $\mathrm{Q}-\mathrm{Y}$, Clark $\mathrm{OH}$, Siperstein AE. A critical analysis of intraoperative time utilization in laparoscopic adrenalectomy. Surgical Endoscopy And Other Interventional Techniques. 2002; 16(2):258-62.

24. Shen WT, Kebebew E, Clark OH, Duh Q-Y. Reasons for conversion from laparoscopic to open or hand-assisted adrenalectomy: review of 261 laparoscopic adrenalectomies from 1993 to 2003. World journal of surgery. 2004;28(11):1176-9.

25. Tessier DJ, Iglesias R, Chapman WC, Kercher K, Matthews BD, Gorden DL, et al. Previously unreported high-grade complications of adrenalectomy. 2009;23(1):97-102.

26. Kaye DR, Storey BB, Pacak K, Pinto PA, Linehan WM, Bratslavsky $G$. Partial adrenalectomy: underused first line therapy for small adrenal tumors. The Journal of urology. 2010;184(1):18-25.

27. Miron A, Giulea C, Nădrăgea M, Enciu 0. Laparoscopic Partial Adrenalectomy. Chirurgia (Bucur). 2017;112:77.

28. Brauckhoff M, Gimm 0, Thanh PN, Bär A, Ukkat J, Brauckhoff K, et al. Critical size of residual adrenal tissue and recovery from impaired early postoperative adrenocortical function after subtotal bilateral adrenalectomy. Surgery. 2003;134(6):1020-7.

29. Henry J-F, Defechereux T, Raffaelli M, Lubrano D, Gramatica LJWjos. Complications of laparoscopic adrenalectomy: results of 169 consecutive procedures. 2000;24(11):1342-6.

30. Zhang X, Wang B, Ma X, Zhang G, Shi T, Ju Z, et al. Laparoscopic adrenalectomy for beginners without open counterpart experience: initial results under staged training. 2009;73(5):1061-5.

31. Natkaniec M, Pedziwiatr M, Wierdak M, Białas M, Major P, Matłok $\mathrm{M}$, et al. Laparoscopic adrenalectomy for pheochromocytoma is more difficult compared to other adrenal tumors. 2015; 10(3):466.

32. Kercher KW, Novitsky YW, Park A, Matthews BD, Litwin DE, Heniford BTJAos. Laparoscopic curative resection of pheochromocytomas. 2005;241(6):919.

33. David G, Yoav M, Gross D, Reissman PJSE, Techniques OI. Laparoscopic adrenalectomy. 2004;18(5):771-3.

34. Maccabee D, Jones A, Domreis J, Deveney C, Sheppard BJSE, Techniques Ol. Transition from open to laparoscopic adrenalectomy. 2003;17(10):1566-9.

35. Bergamini C, Martellucci J, Tozzi F, Valeri AJSe. Complications in laparoscopic adrenalectomy: the value of experience. 2011; 25(12):3845-51.

36. Eto $M$, Harano M, Koga $H$, Tanaka M, Naito SJljou. Clinical outcomes and learning curve of a laparoscopic adrenalectomy in 103 consecutive cases at a single institute. 2006;13(6):671-6.

37. Broome JT, Solorzano CC. Impact of surgical mentorship on retroperitoneoscopic adrenalectomy with comparison to transperitoneal laparoscopic adrenalectomy. The American surgeon. 2013;79(2):162-6.

38. Way LW, Stewart L, Gantert W, Liu K, Lee CM, Whang K, et al. Causes and prevention of laparoscopic bile duct injuries: analysis of 252 cases from a human factors and cognitive psychology perspective. Annals of surgery. 2003;237(4):460. 